\title{
Climate Change and Alien Species in South Africa
}

\author{
Ulrike M. Irlich, David M. Richardson, Sarah J. Davies \\ and Steven L. Chown
}

\author{
Centre for Invasion Biology, Department of Botany and Zoology, \\ Stellenbosch University, Matieland, South Africa
}

\begin{abstract}
South Africa has a long history of humanmediated introductions of species from all major taxonomic groups. Close to 9000 alien terrestrial plant species have been introduced, and all of the country's biomes have already been invaded. Invasive species are threatening the country's ecosystems in numerous ways, but the effect of climate change on these invasions is predicted to be complex and cascading and remains poorly understood. The relationship between climate and invasive species biology is well established, and there is no question that climate change will influence the ecology of invasive species significantly. If left unmanaged, these effects are expected to increase substantially. Besides terrestrial plants, numerous animals have also invaded the country's landscapes. South Africa's freshwater ecosystems have been invaded by both alien as well as extralimital introductions (indigenous species outside their historical extent of occurrence). The status of invasion in the marine environment remains poorly studied, and knowledge of the status of invasions and predictions regarding the impacts of climate change remain largely speculative. This chapter highlights the current status of invasions in South Africa and discusses some of the direct and indirect effects climate change is likely to have on these invasions.
\end{abstract}

\section{Dedication}

We dedicate this chapter to the memory of Phil Hockey, who had an enduring interest in avian range expansions and has made their study so much more straightforward through his significant contributions to ornithology.

\section{Introduction}

South Africa covers 1.22 million $\mathrm{km}^{2}$, about $2 \%$ of the world's surface area, and has a coastline of about $2800 \mathrm{~km}$. The country has a warm, temperate climate and is mostly arid, with large parts receiving less than $500 \mathrm{~mm}$ rainfall annually, especially the west, which is drier than the east (Fig. 9.1) (O’Brien, 1998; van Rensburg et al., 2002). Nine major biomes (Desert, Succulent Karoo, Nama-Karoo, Fynbos, Albany Thicket, Grassland, Savannah, Forest and Indian Ocean Coastal Belt), each with distinct bioclimatic regimes, characterize the country (Mucina and Rutherford, 2006), which also includes three biodiversity hotspots (Cape Floristic Region, Maputaland-PondolandAlbany and the Succulent Karoo). It is home to about $10 \%$ of the world's plant species, $13 \%$ of bird and mammals and $23 \%$ of marine inhabitants, with high levels of endemism in all groups (DEAT, 1997; EWT, 2002). South Africa also governs the Prince 


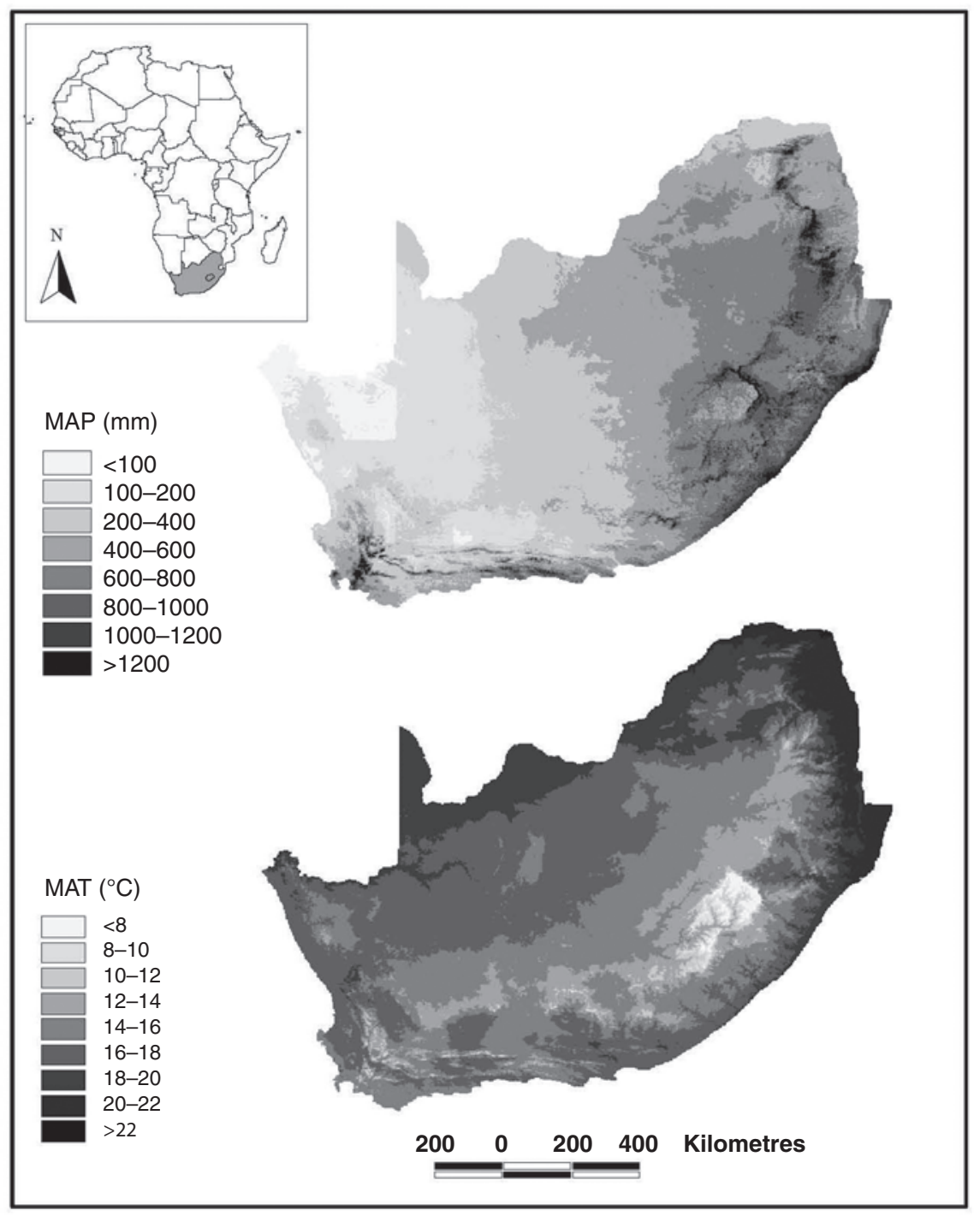

Fig. 9.1. Mean annual temperature (MAT) and precipitation (MAP) for South Africa. Data from the South African Atlas of Agrohydrology and Climatology (Schulze et al., 1997; interpolated $1^{\prime} \times 1^{\prime}$ data).

Edward Island archipelago in the subAntarctic, which lies approximately $1770 \mathrm{~km}$ south-east of Port Elizabeth, South Africa, and has a cool, moist climate characterized by two major biomes (Tundra and Polar Desert) and many distinct habitat types (Chown and Froneman, 2008).

South Africa has a long history of humanmediated introductions of organisms from all the major taxonomic groups (Richardson et al., 2003). Cattle, sheep, goats, dogs and burweed were introduced approximately 2000 years ago as humans migrated southwards, but the arrival of European settlers in the mid-17th century led to a large increase in introductions (Macdonald et al., 1986a). At present, all biomes are invaded, with the highest density of alien 
species occurring in the eastern parts of the country (Rouget et al., 2004; Richardson et al., 2005; Chown and Froneman, 2008; Spear and Chown, 2009). The prominence of alien trees and shrubs as major invaders of terrestrial systems is an unusual feature of South Africa's invasive biota; grasses and other herbaceous species dominate invasive floras in most other parts of the world (Richardson et al., 1997).

Approximately 8750 alien terrestrial plant species from all growth forms are known to be present, and at least 180 of these are currently invasive (Table 9.1; Richardson et al., 2011). At least 771 species of alien trees have been introduced to South Africa (von Breitenbach, 1990). The diversity of bioclimates in South Africa provides niches for species from tropical, temperate and Mediterranean climate regions. Most invasive alien plants from tropical regions are South American, while northern temperate species have originated mostly from Europe or Asia. Australia has

Table 9.1. Current estimates of the number of alien and invasive species (sensu Pyšek et al., 2004) in South African terrestrial and aquatic habitats.

\begin{tabular}{|c|c|c|c|}
\hline & $\begin{array}{l}\text { Number of alien } \\
\text { species }\end{array}$ & $\begin{array}{l}\text { Number of } \\
\text { invasive species }\end{array}$ & Sources \\
\hline \multicolumn{4}{|l|}{ Terrestrial } \\
\hline Plants $^{a}$ & 8750 & 199 & $\begin{array}{l}\text { Macdonald et al., 2003; Richardson et al., } \\
2011\end{array}$ \\
\hline Mammals & 50 & 10 & Richardson et al., 2011 \\
\hline Birds & 77 & 7 & Dean, 2000; van Rensburg et al., 2011 \\
\hline Reptiles & 275 & 0 & van Wilgen et al., 2010 \\
\hline Amphibians & 14 & 0 & $\begin{array}{l}\text { van Rensburg et al., 2011; N.J. van Wilgen, } \\
\text { Stellenbosch, } 2010 \text { personal } \\
\text { communication }\end{array}$ \\
\hline Arthropods ${ }^{b}$ & 305 & Unknown & Lach et al., 2002; Macdonald et al., 2003 \\
\hline Molluscs & 34 & 10 & Herbert, 2010 \\
\hline Microbes & Unknown & Unknown & Pimentel et al., 2001 \\
\hline \multicolumn{4}{|l|}{ Freshwater } \\
\hline Plants & 23 & 13 & Hill, 2003; Macdonald et al., 2003 \\
\hline Fish (freshwater) ${ }^{\mathrm{c}}$ & 58 & 37 & Macdonald et al., 2003 \\
\hline Crayfish & 4 & 4 & de Moor, 2002 \\
\hline Molluscs & 10 & 4 & Appleton, 2003 \\
\hline $\begin{array}{l}\text { Fish parasites/ } \\
\text { diseases }\end{array}$ & 8 & 8 & Macdonald et al., 2003 \\
\hline \multicolumn{4}{|l|}{ Marine $^{d}$} \\
\hline Plants/algae & $6(4)$ & & Mead et al., 2011 \\
\hline Crustaceans & $22(11)$ & 2 & Mead et al., 2011 \\
\hline Insects & 1 & & Mead et al., 2011 \\
\hline Molluscs & $12(9)$ & 1 & Mead et al., 2011 \\
\hline Fish & 1 & & Mead et al., 2011 \\
\hline Other & $43(15)$ & 1 & Mead et al., 2011 \\
\hline
\end{tabular}

Notes: aAt least 771 tree species have been introduced to South Africa over the past 300 years (von Breitenbach, 1990); ${ }^{b}$ numerous insect species were introduced as biocontrol agents; ${ }^{\mathrm{C} 33}$ extraregional (species from outside South Africa) and 25 extralimital (indigenous species outside their historical extent of occurrence); ${ }^{d}$ number of cryptogenic species (species of unknown origin) in brackets. 
been the largest contributor of southern temperate invasive plant species (Henderson, 2006). The most important aquatic weeds are from tropical South America (Henderson, 2006; Coetzee et al., 2011). Many terrestrial invertebrate species have been introduced and have become invasive, including several that are pests of agriculture and which have substantial impacts on biodiversity, such as the Argentine ant, Linepithema humile (Annecke and Moran, 1982; Bond and Slingsby, 1984; Herbert, 2010).

Aquatic invertebrate invaders have not been well studied, but several molluscs are important, including Aplexa marmorata, Lymnaea columella, Physa acuta and Tarebia granifera, which are established in the freshwater ecosystems of the Kruger National Park (de Kock and Wolmarans, 2008). Alien freshwater fish have originated from South African river systems through inter-basin transfers (extralimital introductions; approximately 25 species) as well as extraregional introductions (species from outside South Africa; 33 species) (Table 9.1; Macdonald et al., 2003).

In contrast to terrestrial plant invasions, far fewer terrestrial vertebrates have invaded South African ecosystems, and no extraregional amphibian or reptile species are currently considered invasive, although several species are established (van Wilgen et al., 2008a; van Rensburg et al., 2011). Few bird species have invaded, and those that have are commensals (Table 9.1; Dean, 2000). Among the mammals, commensal rodent species which pose substantial human health risks through their vector status are in a state of dynamic change: a recently discovered introduction, Rattus tanezumi, is widespread (Taylor et al., 2008). Many indigenous mammal species have been moved intentionally outside of their historical ranges in South Africa. Such extralimital introductions have led to homogenization of the fauna (Spear and Chown, 2008, 2009). Species have also been introduced from outside South Africa (extraregional introductions) and, after the USA, South Africa is home to more alien ungulate species than any other country.

\section{Assessing the Influence of Climate Change on Invasive Species}

The impacts of invasive species on South African ecosystem services, biodiversity and the economy are multifaceted. Although these have not been quantified comprehensively, some countrywide assessments have been made, looking at all major taxonomic groups (van Wilgen et al., 2001; Pimentel, 2002; van Wilgen and Richardson, 2009; van Rensburg et al., 2011). The effect of climate change on these invasions is little understood. However, the extensive research conducted on invasive species elsewhere does enable several informed predictions regarding the possible impact and effect of climate change on invasive species to be made.

\section{Direct effects}

The most direct effect of a changing climate on invasive species will be through changes to distribution and life history as a consequence of altered patterns of precipitation and temperature and the increased frequency of extreme events, such as floods and droughts (Hobbs and Mooney, 2005). Kruger and Sekele (2012) found that since the 1960s, warm extreme temperatures have increased, while cold extreme temperatures have decreased, and this pattern has been observed across the country. For South Africa's interior, annual mean temperatures are expected to increase by $2.5-3.5^{\circ} \mathrm{C}$ by 2050 , while the coastal regions could experience temperature increases of up to $2^{\circ} \mathrm{C}$ (Knoesen et al., 2009). The increase in temperature will be accompanied by increased evaporation and the east to west rainfall gradient (Fig. 9.1) is likely to be exacerbated. A recent study investigated the precipitation trends over the past century and found no evidence of changes in rainfall patterns for large parts of the country, while only some areas showed increases or decreases in precipitation trends (Kruger, 2006). However, it is predicted that by 2100 the largest part of the country could experience increased rainfall, with only the 
west coast (Succulent Karoo and the western parts of the Fynbos biome) predicted to become more arid (Knoesen et al., 2009). Projected rainfall anomalies include floods, which show no clear pattern, and short droughts, which are expected to decrease in frequency; current patterns of longer duration droughts are unlikely to change (Knoesen et al., 2009). These direct effects of climate change are likely to drive substantial changes to the geographic ranges of both indigenous and alien species (Richardson et al., 2000; Erasmus et al., 2002; Rouget et al., 2004; Huntley and Barnard, 2012). The range shift of species due to climate change is expected to be similar to natural dispersal, with leading edge range shifts, but longdistance dispersal and movement via corridors also needs to be considered (Tolley et al., 2008; Wilson et al., 2009). This is likely to be more important for alien species, especially those that are frequently dispersed by humans (Trakhtenbrot et al., 2005). Following the changes in rainfall patterns, more alien species may appear in the eastern parts of the country (i.e. tropical species) than in the western arid parts (Rouget et al., 2004).

Assessments of the effects of climate change on indigenous and invasive biota must also consider changes in ecosystem function that alter invasibility. For example, changes in the frequency and intensity of extreme events such as storms, fires, droughts and floods have the potential to increase ecosystem susceptibility to invasion (Hobbs and Mooney, 2005). Changing precipitation and rainfall regimes may also alter the demographic distribution of $C_{3}$ and $\mathrm{C}_{4}$ plants, which will drive crucial changes in fire regimes (Wigley et al., 2010; Higgins and Scheiter, 2012). Increases in carbon dioxide concentration $\left(\left[\mathrm{CO}_{2}\right]\right)$ are likely to have major effects on tree-grass dynamics in grasslands and savannahs, because of the different photosynthetic pathways used by the different growth forms. Differential responses of plant species to increased atmospheric $\left[\mathrm{CO}_{2}\right]$ may be driving the expansion and densification of indigenous trees in South African grasslands (Bond and Midgley, 2012) and may alter the relative abundance of $C_{3}$ and $C_{4}$ plants radically in different biomes. This has profound implications for ecosystem functioning and invasibility (Richardson et al., 2000), and such interactions are likely to cause a substantial reshuffling of invasive species in South Africa.

\section{Indirect effects}

Climate change will also affect introduced species indirectly by influencing the nature and intensity of human activities. Biological invasions are closely linked to human activities, particularly trade and the disturbance of natural ecosystems through changes in land use (Le Maitre et al., 2004; Richardson et al., 2005; Thuiller et al., 2007; King and Tschinkel, 2008). The intentional introduction of species for human activities associated with recreation (fishing - Shelton et al., 2008; hunting - Spear and Chown, 2009), the pet trade (van Wilgen et al., 2010) and agriculture (forestry - Richardson, 1998; agriculture and horticulture - Le Maitre et al., 2004) have contributed significantly to invasive species introductions. As humans adapt to novel climatic conditions, the donor and recipient regions of pathways, as well as the intensity with which these are used, may change (Galil et al., 2007).

Changes in land use associated with increased urbanization and economic and infrastructure development are also likely to result in new dispersal corridors (e.g. roadside verges) for invasive species (Kalwij et al., 2008). The intensification of land use may also increase nutrient deposition (e.g. nitrogen, phosphorus) in soil and water, enhancing invasion vulnerability (Richardson et al., 2000; Coetzee et al., 2009). Human settlements adjacent to protected areas may serve as sources of propagules of alien species, as well as drivers of disturbance that render areas inside protected areas more susceptible to invasion (Alston and Richardson, 2006; Foxcroft et al., 2011; Jarošík et al., 2011). Furthermore, in an attempt to curb climate change, carbon sequestration projects are being 
implemented, often in the form of plantations of fast-growing alien trees such as Pinus and Eucalyptus (Christie and Scholes, 1995), trees that have escaped the plantations and are invading the South African landscape. However, some sequestration projects are focusing on rehabilitating degraded rangelands using indigenous species. Such projects should be supported, as carbon storage in the long term has been found to be greater using indigenous than alien species (van Rooyen et al., 2013). As climate change alters human activities, many introduced species may become 'change passengers', with greater exposure to new regions. Overall, human-mediated dispersal of invasive species is well recognized (Trakhtenbrot et al., 2005), and the indirect effects of climate change as outlined above are likely to play a significant role in driving further invasions in South Africa.

\section{A Synopsis of the Current Status of Invasion and the Predicted Effect of Climate Change on Invasive Species}

\section{Terrestrial}

\section{Current status}

Invasive plant species now cover about $8 \%$, or 10 million hectares (Mha), of South Africa's surface area (Le Maitre et al., 2011), equating to approximately 1.813 million condensed hectares, calculated as the percentage invasion (density) as a proportion times the area of the polygon (Marais and Wannenburgh, 2008; van Wilgen et al., 2012). Plant invaders pose a significant threat to South African biodiversity: they have already been implicated in the extinction of at least 58 plant species in the Cape Floristic Region and are threatening thousands more (Macdonald et al., 2003; Gaertner et al., 2009). Invasive plants are also negatively affecting other groups, such as birds (Allan et al., 1997; Dean et al., 2002) and several invertebrate groups (grasshoppers - Samways and Moore, 1991; ground-living invertebrates - Samways et al., 1996; dung beetles - Steenkamp and
Chown, 1996; spiders - van der Merwe et al., 1996; dragonflies and damselflies - Samways and Taylor, 2004; Samways et al., 2005).

Plant invasions also have a significant impact on South Africa's water resources. An estimated $7 \%$ of mean annual runoff is currently used by invasive plants, with an annual total of US $\$ 773$ million in waterrelated losses (Le Maitre et al., 2011). Invasive plants currently reduce the grazing potential by c.123,000 large livestock units, with an estimated unit-price estimate of US\$329.47 per large livestock unit (Le Maitre et al., 2011). If invasive species continue to spread and degrade grasslands, grazing potential could be reduced by up to $70 \%$ (van Wilgen et al., 2008b). The cost of clearing invasive plant species across the country has been estimated at approximately US $\$ 1.2$ billion (Pimentel, 2002). Currently, the Working for Water programme and a provincial programme in KwaZulu-Natal spend c.US $\$ 80$ million per annum on the clearing and management of alien species. An estimated $42 \%$ of South Africa's arthropod agricultural pests are alien species which cause crop losses and impact food security to the value of approximately US $\$ 1$ billion per annum, with alien weeds and pathogens adding a further US $\$ 3.3$ billion in crop losses annually (Pimentel et al., 2001). For South Africa alone, the total cost of invasive alien plant species has been estimated to be between US $\$ 867$ million (Le Maitre et al., 2011) and US $\$ 1$ billion annually (Pimentel et al., 2001). Many introduced species bring substantial economic benefits, but the environmental impacts of some of these species result in complex conflicts of interest. Considerable attention is being given to formulating trade-offs to resolve such conflicts; for example, in the case of forestry trees that also cause major problems as invasive species (van Wilgen et al., 2011; van Wilgen and Richardson, 2012).

At least 50 mammal species have been introduced to South Africa, many intentionally for pest control, pets, food or as the source of other animal products, as well as for hunting and ornamental purposes (Table 9.1; van Rensburg et al., 2011). In addition to domestic animals, such as goats, 
sheep and cattle, 38 ungulate species have also been introduced or translocated within the country, largely for the game ranching and hunting industries (Spear and Chown, 2009). At least 77 bird species have been introduced to South Africa, but only a few commensal species have established successfully (Table 9.1; Dean, 2000; van Rensburg et al., 2011). Approximately 275 species of reptiles and at least 14 species of amphibians have been introduced to South Africa, mainly through the pet trade (van Wilgen et al., 2010; N.J. van Wilgen, Stellenbosch, 2010, personal communication). Although some alien reptile species have established feral populations, none are currently invasive (Richardson et al., 2011; van Rensburg et al., 2011). Three amphibian species have established extralimital populations in the Western Cape and are invading (Measey and Davies, 2011). South African ecosystems appear resistant to invasion by extraregional alien amphibians and reptiles, but this may be an artefact of low propagule pressure and the short residence time of these species. Increasing rates of introduction and changing environmental conditions may well render ecosystems more susceptible to invasion.

Data on alien invertebrates in South Africa are limited. At least 24 alien spider species have been recorded (Macdonald et al., 2003). Of the 34 mollusc species known to have been introduced, 28 are established and 10 of these are invasive (Table 9.1; Herbert, 2010). Of the 40 top crop pests in South Africa, about 17 species are alien (Pimentel, 2002). Some insect invaders with potentially detrimental effects on biodiversity include the varroa mite (Varroa destructor) and the Argentine ant (L. humile; Lach et al., 2002). While not invasive, over 225 insect species have been introduced as biological control agents against insect pests and a further 56 species to control weeds (Lach et al., 2002; Macdonald et al., 2003; Klein, 2011). Little information is available on the status of alien microbes (viruses, bacteria, most fungi and most single-celled organisms) or their impact on the environment, human health and the economy (Table 9.1; Pimentel et al., 2001).

\section{Predictions}

South Africa is expected to be affected significantly by climate change over the next few decades. Mean annual temperatures are expected to rise by $2.5-3.5^{\circ} \mathrm{C}$ by 2050 (Knoesen et al., 2009). Large parts of the country are expected to experience more extreme rainfall events, which are likely to lead to the increased frequency as well as severity of floods. Predictions suggest an increase in shorter (1- to 2-year) droughts, whereas no change is predicted in longer (3 consecutive years or longer) drought events (Knoesen et al., 2009). Raised levels of atmospheric $\left[\mathrm{CO}_{2}\right]$ have been shown to increase photosynthesis, plant water-use efficiency and biomass in many plant species (Bazzaz, 1990; Ziska, 2003), and both indigenous and alien woody plants will benefit from this $\mathrm{CO}_{2}$ enrichment (Bond and Midgley, 2012; Higgins and Scheiter, 2012). The increased growth rate of woody species and their enhanced ability to survive fires is likely to drive a marked increase in the invasion of grasslands by woody plants, as is being observed with the range expansion of Prosopis species in North America (Polley et al., 2002). Through this increased plant growth, the carbon:nitrogen ratio in the leaves may be modified, resulting in nitrogen becoming the limiting nutrient for herbivorous insects. Such altered plantherbivore interactions could result in increased leaf herbivory and decreased insect growth, but ecosystem effects are variable (Coviella and Trumble, 1999; Lindroth, 2010). One consequence of rising $\mathrm{CO}_{2}$ may well be a reduced ability of crop species to resist invasive herbivores (Zavala et al., 2008), though such interactions have not been explored for the region. In the mesic parts of South Africa, increased wateruse efficiency resulting from increased atmospheric $\left[\mathrm{CO}_{2}\right]$ could contribute to flooding events due to waterlogged soil, while in arid areas it could open up niches for alien species that require more water (Smith et al., 2000; Betts et al., 2007; but see Piao et al., 2007).

The response of the Prosopis species complex to climatic factors in South Africa 
has been examined using bioclimatic modelling and by inferring the processes that have driven range changes in different parts of the invasive range (Richardson et al., 2000). Prosopis has invaded the arid and semi-arid areas of South Africa, covering $19 \%$ of the total invaded area, or an estimated 1.8 Mha (Marais and Wannenburgh, 2008), posing a significant threat to biodiversity (Steenkamp and Chown, 1996; Dean et al., 2002) and grazing resources (van Wilgen and Richardson, 2009). Warming alone is expected to decrease substantially the suitable area for this species, driving an eastward shift in range (Richardson et al., 2000). However, rainfall is predicted to increase across the area currently occupied by Prosopis; this could facilitate further spread in all directions, particularly to the currently arid western parts. Decreases in fire frequencies and increased grazing intensity will also alter spread by allowing this taxon to move eastwards and northwards, respectively (Richardson et al., 2000).

With increased urbanization and economic development, natural habitats are being transformed to meet the needs of a rapidly growing human population. Changes in urbanization and development associated with land use and land transformation in response to a changing climate are difficult to forecast for South Africa. Propagule pressure of alien species has been found to be closely related to human activities (Lockwood et al., 2005). Hence, it is likely that climate-driven changes to the spatial patterns of human activities will affect propagule availability significantly, exposing many new areas to invasion by alien species. In the absence of effective policy implementation, increased demands for goods and services may also therefore lead to heightened pressure from invasive species, as seen elsewhere (see Hulme et al., 2008).

\section{Fresh water}

\section{Current status}

South Africa's freshwater systems have been invaded by at least 58 alien fish species, 33 of which are extraregional introductions and the remaining 25 extralimital transfers (Table 9.1; Richardson et al., 2011). At least 37 of these alien species are considered detrimental to the aquatic habitats that they occupy. Predatory invasive fish reduce the abundance of indigenous fish and insects, and may cause local extinctions (Weyl and Lewis, 2006; Lowe et al., 2008; Shelton et al., 2008). Four freshwater crayfish have established following escape from aquaculture (de Moor, 2002). About ten freshwater gastropod species have been introduced, two of which are invasive and a further two undergoing range expansion (Appleton, 2003). At least eight fish parasites and diseases have also been introduced to South Africa (Macdonald et al., 2003). In addition to the aquatic animal invaders, South Africa has also been invaded by at least 21 aquatic and wetland plant species (Table 9.1; Henderson and Cilliers, 2002). These have caused extensive disruption to South Africa's freshwater systems by interrupting water flow, degrading water quality, increasing evapotranspiration and increasing erosion (Le Maitre et al., 2011; van Wilgen and de Lange, 2011).

The major pathways of introduction for South African freshwater invaders have been the aquarium trade, aquaculture and introductions of fish for sports and food, while most extralimital introductions are attributable to inter-basin transfers (Macdonald et al., 1986a; Richardson et al., 2011). The introduction and translocation of organisms often includes the transfer of their parasites, particularly in the case of fish. Furthermore, fish translocations have resulted in hybridization with closely related species; e.g. Nile tilapia (Oreochromis niloticus) hybridizes with other tilapia species (van der Waal and Bills, 2000; Canonico et al., 2005).

\section{Predictions}

Climate change will undoubtedly affect South Africa's aquatic ecosystems through increased temperatures and evaporation and through altered rainfall patterns. Increases in water temperature, together 
with decreased water flow, have been predicted for southern Africa. This could result in deterioration in water quality, affecting freshwater ecosystems and the utilization of water resources by humans (van Vliet et al., 2013). Due to these changes, land use is likely to change in response to the changing climate. Urbanization, human population growth and economic development are increasing the pressure on South Africa's water supplies over much of the country. This will increase the demand for dam construction and inter-basin transfers, which will lead to more transfers of organisms between regions (both species native to South Africa and alien species) (Kolar and Lodge, 2000; Johnson et al., 2008). The increased transformation of natural environments for agriculture will alter aquatic systems by increasing the runoff of agricultural effluent into rivers and dams, with impacts on water quality (de Villiers, 2007). The eutrophication of freshwater systems often makes ecosystems less suitable for indigenous species and more suitable for alien species, as eutrophication acts as a disturbance event and some alien species might be better adapted to nutrientrich environments than indigenous species (Byers, 2002). More intensive agriculture may also alter water temperature (Kolar and Lodge, 2000), which may reduce habitat quality for freshwater species such as dragonflies and damselflies (Samways and Taylor, 2004). However, increased evaporation and increased aridity in the western parts of the country will decrease annual runoff and river flow. The predicted increases in the frequency and severity of precipitation events across the country will have marked effects on freshwater systems (Knoesen et al., 2009).

Some aquatic weeds have been brought under control successfully through the introduction of biological control agents (Coetzee et al., 2011). The effect of climate change on biocontrol agents has been poorly investigated. However, variable levels of success in controlling water hyacinth (Eichhornia crassipes) have been ascribed to different climatic conditions among invaded sites, pointing to the effect climate may have on biocontrol agents (Coetzee et al., 2011). In the case of the water hyacinth and its biocontrol agents, climate change could increase the effectiveness of the agents if conditions become more favourable and enhance the reproductive success of the insects.

Large physiological tolerance ranges of the four alien crayfish species (de Moor, 2002) indicate that these species could potentially spread across large areas and will not be much affected by climate change. This could prove problematic, as freshwater molluscs and crayfish act as intermediate hosts for parasites such as lung fluke and bilharzias, affecting human health (de Kock and Wolmarans, 1998; de Moor, 2002). The potential effects of climate change on other aquatic invaders have not been assessed, and research is required to understand the full range of possible outcomes.

\section{Marine}

\section{Current status}

Alien marine organisms have arrived in South Africa mainly in the ballast water of ships and attached to ships' hulls as fouling organisms, with fewer than ten introductions associated with mariculture (Mead et al., 2011). South Africa's marine habitats support at least 83 alien species and 37 cryptogenic species (species of unknown origin; Mead et al., 2011), a drastic increase from the lists of 22 alien and 18 cryptogenic species published in 2009 (Griffiths et al., 2009). The lack of knowledge of species distributions and life-history characteristics complicates the task of making informed predictions regarding the potential effects of climate change on indigenous and alien biodiversity. Furthermore, the number of species that are invasive and the potentially environmental and economic impacts of the invaders remains poorly documented. South Africa has 259 estuaries, all of which are extremely vulnerable ecologically. They are being affected by marine and freshwater invasions (Robinson et al., 2005), as well as by invasions along riparian zones, which 
affect the freshwater discharge into estuaries (Richardson and van Wilgen, 2004).

\section{Predictions}

There is limited knowledge of indigenous and alien biodiversity along the South African coastline and a lack of data on the species distributions and life-history characteristics of most species. Despite recent advances (e.g. Mead et al., 2011), the number of species that are invasive, as well as the potential environmental and economic impacts of the invaders, are not well known. Predictions regarding the responses of marine species to climate change are therefore largely speculative.

The effects of climate change on the marine environment are predicted to be complex and cascading. Between 1985 and 2006, sea surface temperatures of the Agulhas Current have increased $0.7^{\circ} \mathrm{C}$ per decade, while increases of $1.1^{\circ} \mathrm{C}$ per decade have been noted at $500 \mathrm{~m}$ depth (Rouault et al., 2009). Sea surface temperatures are expected to increase by a further $1-3^{\circ} \mathrm{C}$ before 2050 (Clark, 2006). Sea levels have risen $10-15 \mathrm{~mm}$ over the past century and are expected to rise an additional $25 \mathrm{~cm}$ by 2050. The frequency and severity of storms will increase; this, in combination with sea level rise, will affect the intertidal zone negatively through coastal erosion, as seen in KwaZulu-Natal in 2007 (Smith et al., 2007). Atmospheric $\left[\mathrm{CO}_{2}\right]$ heavily influences the marine environment, and the acidity of surface waters will decrease by $0.4 \mathrm{pH}$ units by the end of the century, accompanied by a decline in calcium carbonate saturation levels (Clark, 2006). Increases in ultraviolet radiation are expected to affect photosynthetic rates negatively. The changes are expected to affect the indigenous and alien biota profoundly, either individually or in combination.

Globalization together with climate change will add new trade paths and alter existing ones, across the oceans as well as across land (Galil et al., 2007). These will aid the movement of alien species in ballast water, as well as hull-fouling organisms. Furthermore, it has been found that the pollution of harbours by heavy metals affects the indigenous biota negatively and increases the dominance of invasive species (Piola and Johnston, 2008).

Changes in precipitation patterns across the country may result in changes in runoff, and subsequently affect the marine and estuarine environments (Clark et al., 2000). The greatest potential effect on South Africa's marine biota due to climate change may be from changes in pressure systems, which are expected to manipulate large-scale oceanographic processes, particularly the upwelling associated with the Benguela region (Clark, 2006). All these climatic alterations will disturb marine environments, making them more susceptible to invasion. Invasive species from lower latitudes are likely to arrive in South African oceanic systems, and warm-water species are likely to become more abundant (Carlton, 2000; Drinkwater etal., 2010). Consequently, an overall decline in cold-water indigenous species can be expected.

The response of alien marine organisms to climate change has not been investigated specifically in South Africa, but some predictions can be made by relating the physiological tolerances of a given species to predicted temperature shifts. For example, Balanus glandula, a marine invader with a preference for cool, temperate waters, is currently distributed along the western coast, and its range along the south coast is limited by the warmer waters of the Agulhas region. This species could become less abundant with increased ocean temperatures, as it only tolerates temperatures below $17^{\circ} \mathrm{C}$ (Laird and Griffiths, 2008). The invasion of the European green crab (Carcinus maenas) is currently limited to intertidal sites with low wave exposure (Griffiths et al., 2009). Changes in storm frequency and severity resulting in increased wave action could induce local extinction of this species. The Mediterranean mussel (Mytilus galloprovincialis) affects local mussel diversity negatively by displacing indigenous species on the west coast of South Africa. It seems to prefer cool, temperate conditions and is limited by subtropical environments (Branch and Steffani, 2004), but it is capable 
of surviving high sea temperatures (Rajagopal et al., 2005), and the temperature range for spawning and larval survival is relatively broad (Chícharo and Chicharo, 2000). Wave action has been shown to cause higher mortality in M. galloprovincialis, and thus its invasiveness could decline with increasing wave action as a result of climate change (Zardi et al., 2008).

\section{Southern Ocean islands}

Marion Island, the larger of the two islands in the Prince Edward group, is permanently occupied by a research team, whereas Prince Edward Island is visited only occasionally. The islands have a cool, moist climate, generally very stable, but temperature has increased steadily over the past few centuries and precipitation has declined (Smith and Steenkamp, 1990; Smith, 2002; le Roux and McGeoch, 2008). The Prince Edward Islands have been invaded by numerous alien species, the numbers of which are correlated with the numbers of human visitors during the last two centuries (Chown et al., 1998). Because of the much greater number of visitors to Marion, this island has more alien species. Introductions to these islands have been both accidental and intentional. After the impact of the unintentional introduction of the feral house mouse (Mus musculus domesticus) on Marion Island was noted, the domestic cat (Felis catus) was introduced to alleviate the problem. However, the cats became feral, killing thousands of seabirds, resulting in the active removal of the cats from the island (Chown and Froneman, 2008). The islands have been invaded by at least 13 species of vascular plants (three on Prince Edward) and 18 species of terrestrial invertebrates (one on Prince Edward) (Frenot et al., 2005).

Global environmental change, especially rising temperatures, ocean acidification and changes in sea-ice distribution are of immediate conservation concern for the Prince Edward Islands (Chown et al., 2012). With climate change, the islands are expected to become warmer and drier. This could open up niches for new alien species to occupy the islands and assist in the spread of established aliens (Frenot et al., 2005; Chown et al., 2012).

\section{New Threats}

Climate change poses a major challenge for the management of alien species in South Africa on many fronts. Besides rearranging the distribution and abundance of species that are already invasive in the country, changing climates will alter the performance of other alien species already in the country but which are not invasive - either because current conditions are suboptimal for them or because they have not had enough time to invade. Dealing with 'invasion debt' (the latent expansion of exotic species populations) must be part of a comprehensive strategy for the long-term management of alien species. Nel et al. (2004) identified 85 emerging plant invaders - species that currently have little impact on natural or semi-natural ecosystems in South Africa but which are known to have invasive tendencies. Many of these species are likely to flourish under a changing climate, and management and control strategies need to be responsive to these dynamics.

The changing needs of humans will drive the need for new introductions. Interest in biofuels is growing due to global economic trends and the need to reduce dependence on fossil fuels. Although the cultivation of alien plants for the production of biofuels may, in some cases, have clear economic benefits, there are many environmental costs that need to be considered, including the problem that many of the species most suitable for biofuel production are notorious invasive species (Raghu et al., 2006; Blanchard et al., 2011). Similarly, invasions have resulted and can be expected where plants are cultivated in carbon sequestration projects (Christie and Scholes, 1995; de Wit et al., 2001).

Invasion meltdown, the reshuffling and disassembly of communities, may result from novel interactions among species, invasive and indigenous, resulting sometimes in beneficial, but largely detrimental, effects on species or entire ecosystems 
(Simberloff and Von Holle, 1999; O'Dowd et al., 2003). It is possible that more species indigenous to South Africa may become invasive in parts of the country outside their natural ranges as a result of ongoing humanmediated translocation (Spear and Chown, 2009) or climatic shifts. However, differentiating between unassisted change (i.e. climate change-related only) from directly human-assisted change (i.e. alien invasive species) is a challenge for invasion biology. While the enemy release hypothesis (the ability to thrive in a new environment free of the species' natural enemy) might hold for some species, a recent meta-analysis revealed that not all alien species benefited (Chun et al., 2010). Numerous freshwater fish have already spread through inter-basin transfers and now threaten the indigenous biota of these aquatic systems (Macdonald et al., 2003). The hadeda ibis (Bostrychia hagedash - Macdonald et al., 1986b) and the red-billed quelea (Quelea quelea - Oschadleus and Underhill, 2006) have expanded their distributional ranges in South Africa as a response to human activity. Dynamic range shifts of several other bird species have been attributed to a combination of land-use change and climate change (Hockey et al., 2011). The guttural toad (Amietophrynus gutturalis), painted reed frog (Hyperolius marmoratus) and African clawed toad (Xenopus laevis) have been moved within South Africa and are now considered invasive in the Western Cape (Measey and Davies, 2011). However, distinguishing between climate-induced range expansion and human-assisted translocation is not always straightforward (e.g. Tolley et al., 2008; Hockey et al., 2011), and is likely to become more complicated in future.

In the face of climate change, indigenous species may have to be translocated for conservation purposes (Mueller and Hellmann, 2008; Richardson et al., 2009). Conservation planning must take climate change into account, establishing appropriate corridors between conservation areas, protecting areas of evolutionary significance, expanding transfrontier approaches, practising managed relocation and meeting the challenges posed by invasive species.

\section{Prevention and Management}

The prevention and management of biological invasions forms an integral part of South African policy, legislation and government action aimed at protecting the country's biodiversity. Most legislation of direct relevance to the management of biological invasions is incorporated within the Conservation of Agricultural Resources Act (No 43 of 1983), the National Environmental Management: Protected Areas Act (No 57 of 2003) and the National Environmental Management: Biodiversity Act (No 10 of 2004), although many other legal instruments have clauses that can be invoked in this regard (Richardson et al., 2003). Management interventions have been implemented both nationally (Working for Water at US\$66 million year ${ }^{-1}$ ), provincially (KwaZulu-Natal Invasive Alien Species Programme at US $\$ 13$ million year ${ }^{-1}$ ) and regionally (e.g. the Invasive Alien Species Strategy for the Greater Cape Floristic Region). Research and capacitybuilding initiatives include the creation of the DST-NRF Centre of Excellence for Invasion Biology (http://academic.sun. ac.za/cib/), a partnership between government and the tertiary education sector. Biological control of invasive species has proven successful for controlling several invasive species (Coetzee et al., 2011; Klein, 2011). Currently, between 1.6 and $2.6 \%$ of the total of the Working for Water budget is allocated to biological control, substantially less than is spent on chemical and mechanical control (just under $20 \%$ and $80 \%$, respectively) (Le Maitre et al., 2011; van Wilgen and de Lange, 2011). The effective implementation of legislation, creating sufficient capacity to undertake the extension and identification work required to prevent new invasions, and the research capacity to keep pace with changing circumstances are all crucial ingredients of an effective strategy to reduce the rates and impacts of biological invasions in the future.

Merging species distribution models (also called niche models) with mechanistic models has potential for predicting the outcomes of complex interactions involving 
alien species and changing environmental conditions. This has been done for the invasive tree, Schinus molle, in South Africa (Richardson et al., 2010). Although the overall range of $S$. molle is predicted to shrink in South Africa with predicted climate change, the response of the species is likely to be fundamentally different in different biomes. For example, in areas where it is already highly invasive (notably around Kimberley in the Northern Cape), the considerable propagule pressure that already exists, and which will persist, will facilitate persistence and perhaps even drive further spread, even if climate conditions become marginal. In other areas, the changing flow dynamics of rivers (which create microsites for establishment and facilitate dispersal) are likely to shape invasion dynamics in ways that cannot be accommodated in standard species distribution models (Richardson et al., 2010). Ongoing developments in combining mechanistic models with species distribution models could facilitate better predictions.

Overall, the identification of new and emerging invaders, preventing their introduction and managing populations if prevention fails will depend on an informed and aware public, and on science-based policies that take note of the many issues discussed in this chapter. The increased availability of global databases of invasive species is improving our ability to act in preventing further introductions of highrisk species and in calculating and managing the invasion debt. A complete catalogue of all alien species, including those used for agriculture, forestry, horticulture and other purposes, is needed urgently to identify potentially invasive species among already introduced taxa. Proactive early detection and eradication can substantially reduce the costs of control and damage caused by these species (van Wilgen and Richardson, 2009). An important component of mitigation is the effective regulation of the introduction and movement of species. South African legislation to curb such movement is already in place within the National Environmental Management: Biodiversity Act (No 10 of 2004), and the implementation thereof now needs to be addressed. Work will soon start on a National Invasive Species Strategy and Action Plan.

\section{Summary}

South African ecosystems are being affected negatively by a wide range of invasive species. Alien invasions and their effects on terrestrial and freshwater systems are currently better understood than marine alien invasions; these are the most prevalent and urgent problems to biodiversity and food security. However, the lack of knowledge and understanding of marine invasions cannot be ignored. It is also clear that numerous potential and ongoing interactions exist between invasive species and aspects of anthropogenic climate change. Our understanding of many of these interactions is conceptual and theoretical, and more illustrative than definitive. None the less, the relationship between climate and invasive species biology is well established, and there is no question that climate change will significantly influence the ecology of biological invasions in this region. For these reasons, several preventive and management efforts could be adapted to help manage changes to system function and services resulting from the interactions between climate change and invasion.

\section{Acknowledgements}

This work was funded by the DST-NRF Centre of Excellence for Invasion Biology $(C \cdot I \cdot B)$ and the Working for Water Programme through their collaborative research project on 'Research for Integrated Management of Invasive Alien Species'.

\section{References}

Allan, D.G., Harrison, J.A., Navarro, R.A., van Wilgen, B.W. and Thompson, M.W. (1997) The impact of commercial afforestation on bird populations in Mpumalanga Province, South Africa - insights from bird-atlas data. Biological Conservation 79, 173-185. 
Alston, K.P. and Richardson, D.M. (2006) The roles of habitat features, disturbance, and distance from putative source populations in structuring alien plant invasions at the urban/wildland interface on the Cape Peninsula, South Africa. Biological Conservation 132, 183-198.

Annecke, D.P. and Moran, V.C. (1982) Insects and Mites of Cultivated Plants in South Africa. Butterworths, Durban, South Africa.

Appleton, C.C. (2003) Alien and invasive fresh water Gastropoda in South Africa. African Journal of Aquatic Science 28, 69-81.

Bazzaz, F.A. (1990) The response of natural ecosystems to the rising global $\mathrm{CO}_{2}$ levels. Annual Review of Ecology and Systematics 21, 167-196.

Betts, R.A., Boucher, O., Collins, M., Cox, P.M., Falloon, P.D., Gedney, N., Hemming, D.L., Huntingford, C., Jones, C.D., Sexton, D.M.H. and Webb, M.J. (2007) Projected increase in continental runoff due to plant responses to increasing carbon dioxide. Nature 448, 10371041.

Blanchard, R., Richardson, D.M., O'Farrell, P. and von Maltitz, G. (2011) Biofuels and biodiversity in South Africa. South African Journal of Science 107, 19-26.

Bond, W.J. and Midgley, G.F. (2012) Carbon dioxide and the uneasy interactions of trees and savannah grasses. Philosophical Transactions of the Royal Society B Biological Sciences 367, 601-612.

Bond, W.J. and Slingsby, P. (1984) Collapse of an ant-plant mutualism: the Argentine ant (Iridomyrmex humilis) and myrmecochorous Proteaceae. Ecology 65, 1031-1037.

Branch, G.M. and Steffani, C.N. (2004) Can we predict the effects of alien species? A casehistory of the invasion of South Africa by Mytilus galloprovincialis (Lamarck). Journal of Experimental Marine Biology and Ecology 300, 189215.

Byers, J.E. (2002) Impact of non-indigenous species on natives enhanced by anthropogenic alteration of selection regimes. Oikos 97, 449458.

Canonico, G.C., Arthington, A., McCrary, J.K. and Thieme, M.L. (2005) The effects of introduced tilapias on native biodiversity. Aquatic Conservation: Marine and Freshwater Ecosystems 15, 463-483.

Carlton, J.T. (2000) Global change and biological invasions in the oceans. In: Mooney, H.A. and Hobbs R.J. (eds) Invasive Species in a Changing World. Island Press, Washington, DC, pp. 31-53.

Chícharo, L.M.Z. and Chicharo, M.A. (2000) Estimation of the life history parameters of
Mytilus galloprovincialis (Lamarck) larvae in a coastal lagoon (Ria Formosa - south Portugal). Journal of Experimental Marine Biology and Ecology 243, 81-94.

Chown, S.L. and Froneman, P.W. (eds) (2008) The Prince Edward Islands. Land-Sea Interactions in a Changing Ecosystem. Sun Media, Stellenbosch, South Africa.

Chown, S.L., Gremmen, N.J.M. and Gaston, K.J. (1998) Ecological biogeography of southern ocean islands: species-area relationships, human impacts, and conservation. American Naturalist 152, 562-575.

Chown, S.L., et al. (2012) Challenges to the future conservation of the Antarctic. Science 337, 158-159.

Christie, S.I. and Scholes, R.J. (1995) Carbon sequestration in Eucalyptus and Pine plantations in South Africa. Environmental Monitoring and Assessments 38, 231-241.

Chun, Y.L., van Kleunen, M. and Dawson, W. (2010) The role of enemy release, tolerance and resistance in plant invasions: linking damage to performance. Ecology Letters 13, 937-946.

Clark, B.M. (2006) Climate change: a looming challenge for fisheries management in southern Africa. Marine Policy 30, 84-95.

Clark, B.M., Steffani, C.N., Young, S., Richardson, A.J. and Lombard, A.T. (2000) The effects of climate change on marine biodiversity in South Africa. Report prepared for the Foundation for Research Development, South African Country Study on Climate Change, Vulnerability and Adaptation Assessment, Marine Biodiversity Section, Pretoria.

Coetzee, J.A., Hill, M.P. and Schlange, D. (2009) Potential spread of the invasive plant Hydrilla verticillata in South Africa based on anthropogenic spread and climate suitability. Biological Invasions 11, 801-812.

Coetzee, J.A., Hill, M.P., Byrne, M.J. and Bownes, A. (2011) A review of the biological control programmes on Eichhornia crassipes (C. Mart.) Solms (Pontederiaceae), Salvinia molesta D.S. Mitch. (Salviniaceae), Pistia stratiotes L. (Araceae), Myriophyllum aquaticum (Vell.) Verdc. (Haloragaceae) and Azolla filiculoides Lam. (Azollaceae) in South Africa. African Entomology 19, 451-468.

Coviella, C.E. and Trumble, J.T. (1999) Effects of elevated atmospheric carbon dioxide on insectplant interactions. Conservation Biology 13, 700-712.

de Kock, K.N. and Wolmarans, C.T. (1998) A re-evaluation of the occurrence of freshwater molluscs in the Kruger National Park. Koedoe 41, 1-8.

de Kock, K.N. and Wolmarans, C.T. (2008) Invasive 
alien freshwater snail species in the Kruger National Park, South Africa. Koedoe 50, 49-53.

de Moor, I. (2002) Potential impacts of alien freshwater crayfish in South Africa. African Journal of Aquatic Science 27, 125-139.

de Villiers, S. (2007) The deteriorating nutrient status of the Berg River, South Africa. Water SA 33, 659-664.

de Wit, M.P., Crookes, D.J. and van Wilgen, B.W. (2001) Conflicts of interest in environmental management: estimating the costs and benefits of a tree invasion. Biological Invasions 3, 167178.

Dean, W.R.J. (2000) Alien birds in southern Africa: what factors determine success? South African Journal of Science 96, 9-14.

Dean, W.R.J., Anderson, M.D., Milton, S.J. and Anderson, T.A. (2002) Avian assemblages in native Acacia and alien Prosopis drainage line woodland in the Kalahari, South Africa. Journal of Arid Environments 51, 1-19.

DEAT (1997) White paper on the conservation and sustainable use of South Africa's biological diversity. Department of Environmental Affairs and Tourism, Pretoria.

Drinkwater, K.F., Beaugrand, G., Kaeriyama, M., Kim, S., Ottersen, G., Perry, R.I., Pörtner, H.-O., Polovina, J.J. and Takasuka, A. (2010) On the processes linking climate to ecosystem changes. Journal of Marine Systems 79, 374388.

Erasmus, B.F.N., van Jaarsveld, A.S., Chown, S.L., Kshatriya, M. and Wessels, K.J. (2002) Vulnerability of South African animal taxa to climate change. Global Change Biology 8, 679693.

EWT (Endangered Wildlife Trust) (2002) The Biodiversity of South Africa 2002: Indicators, Trends and Human Impacts. Struik, Cape Town.

Foxcroft, L.C., Jarošík, V., Pyšek, P., Richardson, D.M. and Rouget, M. (2011) Protected-area boundaries as filters of plant invasions. Conservation Biology 25, 400-405.

Frenot, Y., Chown, S.L., Whinam, J., Selkirk, P.M., Convey, P., Skotnicki, M. and Bergstrom, D.M. (2005) Biological invasions in the Antarctic: extent, impacts and implications. Biological Reviews 80, 45-72.

Gaertner, M., Den Breeÿen, A., Hui, C. and Richardson, D.M. (2009) Impacts of alien plant invasions on species richness in Mediterraneantype ecosystems: a meta-analysis. Progress in Physical Geography 33, 319-338.

Galil, B.S., Nehring, S. and Panov, V. (2007) Waterways as invasion highways - impact of global climate change and globalization. In: Nentwig, W. (ed.) Biological Invasions. SpringerVerlag, Berlin, pp. 59-74.
Griffiths, C.L., Robinson, T.B. and Mead, A. (2009) The status and distribution of marine alien species in South Africa. In: Rilov, G. and Crooks, J.A. (eds) Biological Invasions in Marine Ecosystems. Springer Verlag, Heidelberg, Germany, pp. 393-407.

Henderson, L. (2006) Comparisons of invasive plants in southern Africa originating from southern temperate, northern temperate and tropical regions. Bothalia 36, 201-222.

Henderson, L. and Cilliers, C.J. (2002) Invasive Aquatic Plants: A Guide to the Identification of the Most Important and Potentially Dangerous Invasive Aquatic and Wetland Plants in South Africa. Agricultural Research Council, Pretoria.

Herbert, D.G. (2010) The Introduced Terrestrial Mollusca of South Africa. SANBI Biodiversity Series 15. South African National Biodiversity Institute, Pretoria.

Higgins, S.I. and Scheiter, S. (2012) Atmospheric $\mathrm{CO}_{2}$ forces abrupt vegetation shifts locally, but not globally. Nature 488, 209-212.

Hill, M.P. (2003) The impact and control of alien aquatic vegetation in South African aquatic ecosystems. African Journal of Aquatic Science 28, 19-24.

Hobbs, R.J. and Mooney, H.A. (2005) Invasive species in a changing world: the interactions between global change and invasives. In: Mooney, H.A., Mack, R.N., McNeely, J.A., Neville, L.E., Schei, P.J. and Waage, J.K. (eds) Invasive Alien Species: A New Synthesis. Island Press, Washington, DC, pp. 310-331.

Hockey, P.A.R., Sirami, C., Ridley, A.R., Midgley, G.F. and Babiker, H.A. (2011) Interrogating recent range changes in South African birds: confounding signals from land use and climate change present a challenge for attribution. Diversity and Distributions 17, 254-261.

Hulme, P.E., et al. (2008) Grasping at the routes of biological invasions: a framework for integrating pathways into policy. Journal of Applied Ecology 45, 403-414.

Huntley, B. and Barnard, P. (2012) Potential impacts of climatic change on southern African birds of fynbos and grassland biodiversity hotspots. Diversity and Distributions 18, 769-781.

Jarošík, V., Pyšek, P., Foxcroft, L.C., Richardson, D.M., Rouget, M. and MacFadyen, S. (2011) Predicting incursion of plant invaders into Kruger National Park, South Africa: the interplay of general drivers and species-specific factors. PloS One 6, e28711.

Johnson, P.T.J., Olden, J.D. and van der Zanden, M.J. (2008) Dam invaders: impoundments facilitate biological invasions into freshwaters. Frontiers in Ecology and the Environment 6, 357-363. 
Kalwij, J.M., Robertson, M.P. and van Rensburg, B.J. (2008) Human activity facilitates altitudinal expansion of exotic plants along a road in montane grassland, South Africa. Applied Vegetation Science 11, 491-498.

King, J.R. and Tschinkel, W.R. (2008) Experimental evidence that human impacts drive fire ant invasions and ecological change. Proceedings of the National Academy of Sciences 105, 20339-20343.

Klein, H. (2011) A catalogue of the insects, mites and pathogens that have been used or rejected, or are under consideration, for the biological control of invasive alien plants in South Africa. African Entomology 19, 515-549.

Knoesen, D., Schulze, R.E., Pringle, C., Summerton, M., Dickens, C. and Kunz, R. (2009) Water for the future: impacts of climate change on water resources in the OrangeSenqu River basin. Report to NeWater, a project funded under the Sixth Research Framework of the European Union. Institute of Natural Resources, Pietermaritzburg, South Africa.

Kolar, C.S. and Lodge, D.M. (2000) Freshwater nonindigenous species: interactions with other global changes. In: Mooney, H.A. and Hobbs, R.J. (eds) Invasive Species in a Changing World. Island Press, Washington, DC, pp. 3-30.

Kruger, A.C. (2006) Observed trends in daily precipitation indices in South Africa: 19102004. International Journal of Climatology 26, 2275-2285.

Kruger, A.C. and Sekele, S.S. (2012) Trends in extreme temperature indices in South Africa: 1962-2009. International Journal of Climatology doi:10.1002/joc.3455.

Lach, L., Picker, M.D., Colville, J.F., Allsopp, M.H. and Griffiths, C.L. (2002) Alien invertebrate animals in South Africa. In: Pimentel, D. (ed.) Biological Invasions: Economic and Environmental Costs of Alien Plant, Animal, and Microbe Species. CRC Press, Boca Raton, Florida, pp. 267-282.

Laird, M.C. and Griffiths, C.L. (2008) Present distribution and abundance of the introduced barnacle Balanus glandula Darwin in South Africa. African Journal of Marine Science 30, 93-100.

Le Maitre, D.C., Richardson, D.M. and Chapman, R.A. (2004) Alien plant invasions in South Africa: driving forces and the human dimension. South African Journal of Science 100, 103-112.

Le Maitre, D.C., de Lange, W.J., Richardson, D.M., Wise, R.M. and van Wilgen, B.W. (2011) The economic consequences of the environmental impacts of alien plant invasions in South Africa. In: Pimentel, D. (ed.) Biological Invasions:
Economic and Environmental Costs of Alien Plant, Animal, and Microbe Species. CRC Press, New York, pp. 295-323.

le Roux, P.C. and McGeoch, M.A. (2008) Changes in climate extremes, variability and signature on sub-Antarctic Marion Island. Climatic Change 86, 309-329.

Lindroth, R.L. (2010) Impacts of elevated atmospheric $\mathrm{CO}_{2}$ and $\mathrm{O}_{3}$ on forests: phytochemistry, trophic interactions, and ecosystem dynamics. Journal of Chemical Ecology 36, 2-21.

Lockwood, J.L., Cassey, P. and Blackburn, T.M. (2005) The role of propagule pressure in explaining species invasions. Trends in Ecology and Evolution 20, 223-228.

Lowe, S.R., Woodford, D.J., Impson, N.D. and Day, J.A. (2008) The impact of invasive fish and invasive riparian plants on the invertebrate fauna of the Rondegat River, Cape Floristic Region, South Africa. African Journal of Aquatic Science 33, 51-62.

Macdonald, I.A.W., Kruger, F.J. and Ferrar, A.A. (eds) (1986a) The Ecology and Management of Biological Invasions in Southern Africa. Oxford University Press, Cape Town.

Macdonald, I.A.W., Richardson, D.M. and Powrie, F.J. (1986b) Range expansion of the hadeda ibis Bostrychia hagedash in southern Africa. South African Journal of Zoology 21, 331-342.

Macdonald, I.A.W., Reaser, J.K., Bright, C., Neville, L.E., Howard, G.W., Murphy, S.J. and Preston, G. (eds) (2003) Invasive Alien Species in Southern Africa: National Reports and Directory of Resources. Global Invasive Species Programme, Cape Town.

Marais, C. and Wannenburgh, A.M. (2008) Restoration of water resources (natural capital) through the clearing of invasive alien plants from riparian areas in South Africa - costs and water benefits. South African Journal of Botany 74, 526-537.

Mead, A., Carlton, J.T., Griffiths, C.L. and Rius, M. (2011) Revealing the scale of marine bioinvasions in developing regions. Biological Invasions 13, 1991-2008.

Measey, G.J. and Davies, S.J. (2011) Struggling against domestic exotics at the southern end of Africa. Frog $\log 97,28-30$.

Mucina, L. and Rutherford, M.C. (2006) The Vegetation of South Africa, Lesotho and Swaziland. Strelitzia 19. South African National Biodiversity Institute, Pretoria.

Mueller, J.M. and Hellmann, J.J. (2008) An assessment of invasion risk from assisted migration. Conservation Biology 22, 562-567.

Nel, J.L., Richardson, D.M., Rouget, M., Mgidi, 
T.N., Mdzeke, N., Le Maitre, D.C., van Wilgen, B.W., Schonegevel, L., Henderson, L. and Neser, S. (2004) A proposed classification of invasive alien plant species in South Africa: towards prioritizing species and areas for management action. South African Journal of Science 100, 53-64.

O'Brien, E.M. (1998) Water-energy dynamics, climate, and prediction of woody plant species richness: an interim general model. Journal of Biogeography 25, 379-398.

O'Dowd, D.J., Green, P.T. and Lake, P.S. (2003) Invasion 'meltdown' on an oceanic island. Ecology Letters 6, 812-817.

Oschadleus, H.D. and Underhill, L.G. (2006) Range expansion of the red-billed quelea, Quelea quelea, into the Western Cape, South Africa. South African Journal of Science 102, 12-13.

Piao, S., Friedlingstein, P., Ciais, P., de NobletDucoudré, N., Labat, D. and Zaehle, S. (2007) Changes in climate and land use have a larger direct impact than rising $\mathrm{CO}_{2}$ on global river runoff trends. Proceedings of the National Academy of Sciences 104, 15242-15247.

Pimentel, D. (ed.) (2002) Biological Invasions: Economic and Environmental Costs of Alien Plant, Animal, and Microbe Species. CRC Press, Boca Raton, Florida.

Pimentel, D., McNair, S., Janecka, J., Wightman, J., Simmonds, C., O'Connell, C., Wong, E., Russel, L., Zern, J., Aquino, T. and Tsomondo, T. (2001) Economic and environmental threats of alien plant, animal, and microbe invasions. Agriculture, Ecosystems and Environment 84, 1-20.

Piola, R.F. and Johnston, E.L. (2008) Pollution reduces native diversity and increases invader dominance in marine hard-substrate communities. Diversity and Distributions 14, 329342.

Polley, H.W., Johnson, H.B. and Tischler, C.R. (2002) Woody invasion of grasslands: evidence that $\mathrm{CO}_{2}$ enrichment indirectly promotes establishment of Prosopis glandulosa. Plant Ecology 164, 85-94.

Pyšek, P., Richardson, D.M., Rejmánek, M., Webster, G.L., Williamson, M. and Kirschner, J. (2004) Alien plants in checklists and floras: towards better communication between taxonomists and ecologists. Taxon 53, 131-143.

Raghu, S., Anderson, R.C., Daehler, C.C., Davis, A.S., Wiedenmann, R.N., Simberloff, D. and Mack, R.N. (2006) Adding biofuels to the invasive species fire? Science 313, 1742-1742.

Rajagopal, S., van der Velde, G., Jansen, J., van der Gaag, M., Atsma, G., Janssen-Mommen, J.P.M., Polman, H. and Jenner, H.A. (2005) Thermal tolerance of the invasive oyster
Crassostrea gigas: feasibility of heat treatment as an antifouling option. Water Research 39, 4335-4342.

Richardson, D.M. (1998) Forestry trees as invasive aliens. Conservation Biology 12, 18-26.

Richardson, D.M. and van Wilgen, B.W. (2004) Invasive alien plants in South Africa: how well do we understand the ecological impacts? South African Journal of Science 100, 45-52.

Richardson, D.M., Macdonald, I.A.W., Hoffmann, J.H. and Henderson, L. (1997) Alien plant invasions. In: Cowling, R.M., Richardson, D.M. and Pierce, S.M. (eds) The Vegetation of Southern Africa. Cambridge University Press, Cambridge, UK, pp. 535-570.

Richardson, D.M., Bond, W.J., Dean, W.R.J., Higgins, S.I., Midgley, G.F., Milton, S.J., Powrie, L.W., Rutherford, M.C., Samways, M.J. and Schulze, R.E. (2000) Invasive alien species and global change: a South African perspective. In: Mooney, H.A. and Hobbs, R.J. (eds) Invasive Species in a Changing World. Island Press, Washington, DC, pp. 303-349.

Richardson, D.M., Cambray, J.A., Chapman, R.A., Dean, W.R.J., Griffiths, C.L., Le Maitre, D.C., Newton, D.J. and Winstanley, T.J. (2003) Vectors and pathways of biological invasions in South Africa - past, present, and future. In: Ruiz, G.M. and Carlton, J.T. (eds) Invasive Species: Vectors and Management Strategies. Island Press, Washington, DC, pp. 292-349.

Richardson, D.M., Rouget, M., Ralston, S.J., Cowling, R.M., van Rensburg, B.J. and Thuiller, W. (2005) Species richness of alien plants in South Africa: environmental correlates and the relationship with indigenous plant species richness. Écoscience 12, 391-402.

Richardson, D.M., et al. (2009) Multidimensional evaluation of managed relocation. Proceedings of the National Academy of Sciences 106, 97219724.

Richardson, D.M., Iponga, D.M., Roura-Pascual, N., Krug, R.M., Milton, S.J., Hughes, G.O. and Thuiller, W. (2010) Accommodating scenarios of climate change and management in modelling the distribution of the invasive tree Schinus molle in South Africa. Ecography 33, 1049-1061.

Richardson, D.M., Wilson, J.R.U., Weyl, O.L.F. and Griffiths, C.L. (2011) South Africa: invasions. In: Simberloff, D. and Rejmánek, M. (eds) Encyclopedia of Biological Invasions. University of California Press, Berkeley, California, pp. 643651.

Robinson, T.B., Griffiths, C.L., McQuaid, C. and Rius, M. (2005) Marine alien species of South Africa status and impacts. African Journal of Marine Science 27, 297-306. 
Rouault, M., Penven, P. and Pohl, B. (2009) Warming in the Agulhas Current system since the 1980's. Geophysical Research Letters 36, L12602, doi:10.1029/2009GL037987.

Rouget, M., Richardson, D.M., Nel, J.L., Le Maitre, D.C., Egoh, B. and Mgidi, T. (2004) Mapping the potential ranges of major plant invaders in South Africa, Lesotho and Swaziland using climatic suitability. Diversity and Distributions 10, 475-484.

Samways, M.J. and Moore, S.D. (1991) Influence of exotic conifer patches on grasshopper (Orthoptera) assemblages in a grassland matrix at a recreational resort, Natal, South Africa. Biological Conservation 57, 117-137.

Samways, M.J. and Taylor, S. (2004) Impacts of invasive alien plants on Red-Listed South African dragonflies (Odonata). South African Journal of Science 100, 78-80.

Samways, M.J., Caldwell, P.M. and Osborn, R. (1996) Ground-living invertebrate assemblages in native, planted and invasive vegetation in South Africa. Agriculture, Ecosystems and Environment 59, 19-32.

Samways, M.J., Taylor, S. and Tarboton, W. (2005) Extinction reprieve following alien removal. Conservation Biology 19, 1329-1330.

Schulze, R.E., Maharaj, M., Lynch, S.D., Howe, B.J. and Melvil-Thompson, B. (1997) South African Atlas of Agrohydrology and Climatology. Beta 1.002. Computing Centre for Water Research, Pietermaritzburg, South Africa.

Shelton, J.M., Day, J.A. and Griffiths, C.L. (2008) Influence of largemouth bass, Micropterus salmoides, on abundance and habitat selection of Cape galaxias, Galaxias zebratus, in a mountain stream in the Cape Floristic Region, South Africa. African Journal of Aquatic Science 33, 201-210.

Simberloff, D. and Von Holle, B. (1999) Positive interactions of nonindigenous species: invasional meltdown? Biological Invasions 1, 21-32.

Smith, A.M., Guastella, L.A., Bundy, S.C. and Mather, A.A. (2007) Combined marine storm and Saros spring high tide erosion events along the KwaZulu-Natal coast in March 2007. South African Journal of Science 103, 274-276.

Smith, S.D., Huxman, T.E., Zitzer, S.F., Charlet, T.N., Housman, D.C., Coleman, J.S., Fenstermaker, L.K., Seemann, J.R. and Nowak, R.S. (2000) Elevated $\mathrm{CO}_{2}$ increases productivity and invasive species success in an arid ecosystem. Nature 408, 79-81.

Smith, V.R. (2002) Climate change in the subAntarctic: an illustration from Marion Island. Climatic Change 52, 345-357.
Smith, V.R. and Steenkamp, M. (1990) Climatic change and its ecological implications at a subantarctic island. Oecologia 85, 14-24.

Spear, D. and Chown, S.L. (2008) Taxonomic homogenization in ungulates: patterns and mechanisms at local and global scales. Journal of Biogeography 35, 1962-1975.

Spear, D. and Chown, S.L. (2009) The extent and impacts of ungulate translocations: South Africa in a global context. Biological Conservation 142, 353-363.

Steenkamp, H.E. and Chown, S.L. (1996) Influence of dense stands of an exotic tree, Prosopis glandulosa Benson, on a savanna dung beetle (Coleoptera: Scarabaeinae) assemblage in southern Africa. Biological Conservation 78, 305-311.

Taylor, P.J., Arntzen, L., Hayter, M., Iles, M., Frean, J. and Belmain, S. (2008) Understanding and managing sanitary risks due to rodent zoonoses in an African city: beyond the Boston Model. Integrative Zoology 3, 38-50.

Thuiller, W., Richardson, D.M. and Midgley, G.F. (2007) Will climate change promote alien species invasions? In: Nentwig, W. (ed.) Biological Invasions. Springer Verlag, Heidelberg, Germany, pp. 197-211.

Tolley, K.A., Davies, S.J. and Chown, S.L. (2008) Deconstructing a controversial local range expansion: conservation biogeography of the painted reed frog (Hyperolius marmoratus) in South Africa. Diversity and Distributions 14, 400-411.

Trakhtenbrot, A., Nathan, R., Perry, G. and Richardson, D.M. (2005) The importance of long-distance dispersal in biodiversity conservation. Diversity and Distributions 11, 173181.

van der Merwe, M.R., Dippenaar-Schoeman, A.S. and Scholtz, C.H. (1996) Diversity of groundliving spiders at Ngome State Forest, Kwazulu/ Natal: a comparative survey in indigenous forest and pine plantations. African Journal of Ecology 34, 342-350.

van der Waal, B.C.W. and Bills, R. (2000) Oreochromis niloticus (Teleostei: Cichlidae) now in the Limpopo River system. South African Journal of Science 96, 47-48.

van Rensburg, B.J., Chown, S.L. and Gaston, K.J. (2002) Species richness, environmental correlates, and spatial scale: a test using South African birds. American Naturalist 159, 566577.

van Rensburg, B.J., Chimimba, C.T., Davies, S.J., Peacock, D.S., Spear, D., van Wilgen, N.J. and Weyl, O.L.F. (2011) Invasive vertebrates of South Africa. In: Pimentel, D. (ed.) Biological 
Invasions: Economic and Environmental Costs of Alien Plant, Animal, and Microbe Species. CRC Press, New York, pp. 325-378.

van Rooyen, M.W., van Rooyen, N. and Stoffberg, G.H. (2013) Carbon sequestration potential of post-mining reforestation activities on the KwaZulu-Natal coast, South Africa. Forestry 86, 211-223.

van Vliet, M.T.H., Franssen, W.H.P., Yearsley, J.R., Ludwig, F. Haddeland, I., Lettenmaier, D.P. and Kabat, P. (2013) Global river discharge and water temperature under climate change. Global Environmental Change (http://dx.doi.org/ 10.1016/j.gloenvcha.2012.11.002, accessed 15 January 2014).

van Wilgen, B.W. and de Lange, W.J. (2011) The costs and benefits of biological control of invasive alien plants in South Africa. African Entomology 19, 504-514.

van Wilgen, B.W. and Richardson, D.M. (2009) Current and future consequences of invasion by alien species: a case study from South Africa. In: Perrings, C., Mooney, H.A. and Williamson, M. (eds) Bioinvasions and Globalization. Oxford University Press, Oxford, UK, pp. 183-201.

van Wilgen, B.W. and Richardson, D.M. (2012) Three centuries of managing introduced conifers in South Africa: benefits, impacts, changing perceptions and conflict resolution. Journal of Environmental Management 106, 56-68.

van Wilgen, B.W., Richardson, D.M., Le Maitre, D.C., Marais, C. and Magadlela, D. (2001) The economic consequences of alien plant invasions: examples of impacts and approaches to sustainable management in South Africa. Environment, Development and Sustainability 3, 145-168.

van Wilgen, B.W., Reyers, B., Le Maitre, D.C., Richardson, D.M. and Schonegevel, L. (2008b) A biome-scale assessment of the impact of invasive alien plants on ecosystem services in South Africa. Journal of Environmental Management 89, 336-349.

van Wilgen, B.W., Dyer, C., Hoffmann, J.H., Ivey, P., Le Maitre, D.C., Moore, J.L., Richardson, D.M., Rouget, M., Wannenburgh, A. and Wilson, J.R.U. (2011) National-scale strategic approaches for managing introduced plants: insights from Australian acacias in South Africa. Diversity and Distributions 17, 1060-1075.

van Wilgen, B.W., Forsyth, G.G., Le Maitre, D.C., Wannenburgh, A., Kotzé, J.D.F., van den Berg, E. and Henderson, L. (2012) An assessment of the effectiveness of a large, national-scale invasive alien plant control strategy in South Africa. Biological Conservation 148, 28-38.

van Wilgen, N.J., Richardson, D.M. and Baard, E.H.W. (2008a) Alien reptiles and amphibians in South Africa: towards a pragmatic management strategy. South African Journal of Science 104, 13-20.

van Wilgen, N.J., Wilson, J.R.U., Elith, J., Wintle, B. and Richardson, D.M. (2010) Alien invaders and reptile traders: what drives the live animal trade in South Africa? Animal Conservation 13 (Suppl. 1), 24-32.

von Breitenbach, F. (1990) National List of Introduced Trees. Dendrological Foundation, Pretoria.

Weyl, O.L.F. and Lewis, H. (2006) First record of predation by the alien invasive freshwater fish Micropterus salmoides L. (Centrarchidae) on migrating estuarine fishes in South Africa. African Zoology 41, 294-296.

Wigley, B.J., Bond, W.J. and Hoffman, M.T. (2010) Thicket expansion in a South African savanna under divergent land use: local vs. global drivers? Global Change Biology 16, 964-976.

Wilson, J.R.U., Dormontt, E.E., Prentis, P.J., Lowe, A.J. and Richardson, D.M. (2009) Something in the way you move: dispersal pathways affect invasion success. Trends in Ecology and Evolution 24, 136-144.

Zardi, G.I., Nicastro, K.R., McQuaid, C.D. and Erlandsson, J. (2008) Sand and wave induced mortality in invasive (Mytilus galloprovincialis) and indigenous (Perna perna) mussels. Marine Biology 153, 853-858.

Zavala, J.A., Casteel, C.L., DeLucia, E.H. and Berenbaum, M.R. (2008) Anthropogenic increase in carbon dioxide compromises plant defense against invasive insects. Proceedings of the National Academy of Sciences 105, 51295133.

Ziska, L.H. (2003) Evaluation of the growth response of six invasive species to past, present and future atmospheric carbon dioxide. Journal of Experimental Botany 54, 395-404. 